\title{
LIQUIDAÇÃO DE SENTENÇA: \\ QUESTÕES CONTROVERTIDAS E A COLOCAÇÃO DO TEMA NO NOVO \\ CÓDIGO DE PROCESSO CIVIL
}

\author{
JUDGEMENT SETTLEMENT: \\ THE THEME AND CONTROVERSIAL ISSUES IN THE NEW CODE OF CIVIL \\ PROCEDURE
}

\section{JOÃO PEREIRA MONTEIRO NETO 1}

\begin{abstract}
RESUMO: O objetivo do presente estudo é demonstrar a conformação do instituto da liquidação de sentença no novo Código de Processo Civil. O tipo de pesquisa empregado é operatório, acompanhado de técnicas bibliográfica e documental, pautado em método indutivo, que visa à análise crítica das normas relativas ao tema, para propiciar, como síntese geral, um estudo de aproveitamento na solução de problemas práticos verificados na praxe forense. O objetivo é tratar de algumas das questões mais polêmicas sobre o assunto à luz das novas disposições legais. Embora a sistemática procedimental e as hipóteses de cabimento da liquidação de sentença não tenham sido alteradas, algumas modificações demonstram a pertinência de revisitar o tema, em razão de sua relevância para a ciência processual.
\end{abstract}

PALAVRAS-CHAVES: Liquidação de sentença. Procedimento. Novo Código de Processo Civil.

\begin{abstract}
The purpose of this study is to demonstrate how the new Code of Civil Procedure covered the institute of judgement settlement. The type of research used is operative, accompanied by bibliographical and documentary techniques, based on an inductive method, which aims at the critical analysis of the rules related to the subject to provide, as an overview summary, a study of utilization in the solution of practical problems found in forensic practice. The intention is to address some of the most controversial issues on the matter in the light of new legal provisions. Although the procedural systematics and the hypothesis of the appropriateness of judgement settlement has remained unchanged, some changes demonstrate the relevance to revisit the theme, because of its relevance to procedural science.
\end{abstract}

KEYWORDS: Judgement settlement. Procedure. New Code of Civil Procedure.

1 Doutorando e Mestre em Direito Processual pela Faculdade de Direito da Universidade de São Paulo. Especialista em Direito Processual Civil pelo Instituto Brasiliense de Direito Público. Membro do Instituto Brasileiro de Direito Processual. Advogado. 


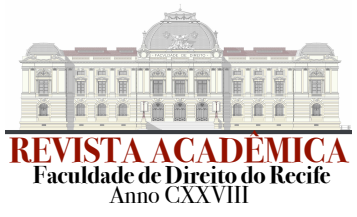

\section{INTRODUÇÃO}

A liquidez não constitui atributo do título, mas uma qualidade da obrigação (arts. $783 \mathrm{e}$ 786 do Código de Processo Civil de 2015). Apesar da antiga redação do art. 586 do CPC/ 1973, que previa a necessidade de a execução fundar-se em título líquido, certo e exigível, a Lei n. 11.382/2006, ainda à luz do Estatuto Processual anterior, corrigiu o equívoco: "a execução para cobrança de crédito fundar-se-á sempre em título de obrigação certa, líquida e exigível”.

A eficácia executória do título ${ }^{2}$ não se confunde com os elementos indispensáveis caracterizadores da obrigação tutelável por via satisfativa, quais sejam, (i) a certeza, (ii) a exigibilidade $^{3}$ e (iii) a liquidez. Conforme mencionado, a redação original do art. 586 do Código de Processo Civil de 1973 incorria em confusão terminológica entre o documento com eficácia executória e os atributos da obrigação.

Em reforço à demonstração desse contraste (título v. obrigação), vale observar que, enquanto a exibição do título constitui pressuposto objetivo do processo executivo, a exigibilidade, no entanto, constitui "elemento da causa de pedir passiva" (ASSIS, 2010, p. 151); não é, portanto, um elemento intrínseco do título, como anteriormente estabelecia a norma processual brasileira.

É possível falar em dois conceitos básicos de liquidez, um de ordem econômica (líquido é tudo aquilo que pode ser exigido, que já existe, que já é passível de conversão em moeda) e outro de ordem jurídica (atributo de obrigação apta a instaurar, com o título executório, a tutela satisfativa). A liquidez reporta-se ao requisito da determinação (quantum)

\footnotetext{
2 O título executivo, sem que se confunda com a obrigação por ele reportada, tem a importância de conceder ao credor a possibilidade de iniciar a tutela satisfativa; título executivo é entendido, então, "come documento che contiene un atto di vario contenuto e che è di accertamento giudiziale nel caso di titolo di formazione giudiziale $e$ che è di prova documentale e di strumento di legittimazione all'esercizio dell'azione esecutiva nel caso di titolo a formazione negoziale" (COMOGLIO, FERRI, TARUFFO, 2011, p. 307).

3 “A exigibilidade é fenômeno externo ao título, é a condição de a ele não se opor nenhum óbice à executoriedade, sem nenhum tipo de impedimento legal” (LUCON, 2000, p. 226).
} 


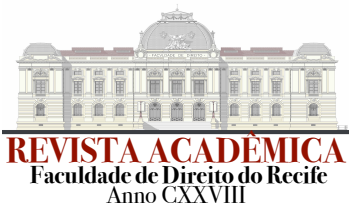

e só abrange, assim, obrigações pecuniariamente quantificáveis resultantes de um título executivo judicial (sentença condenatória genérica) ${ }^{4}$ ou de um título executivo extrajudicial. ${ }^{5}$

A fase de liquidação, prevista nos arts. 509 a 512 do Código de Processo Civil de 2015, visa a apurar o quantum debeatur, com esteio nos elementos previamente definidos pela sentença liquidanda, não os podendo desbordar nem alterar. A fase liquidatória constitui, então, o momento processual de acertamento complementar da sentença genérica, com a finalidade de acrescer ao momento declaratório da sentença condenatória a quantia certa decorrente da sanção previamente aplicada (momento sancionatório da sentença).

\section{SENTENÇAS CONDENATÓRIAS ORDINÁRIA E GENÉRICA}

A sentença condenatória ordinária é completa em relação ao an debeatur e ao quantum debeatur, ${ }^{6}$ é composta por dois momentos lógicos: (i) declaratório, afirma-se a existência da obrigação e se definem os respectivos elementos identificadores; (ii) sancionatório, portador da sanção executiva e que, em termos práticos, representa o elemento instituidor da adequação da tutela executiva. Portanto, apenas a sentença ordinária é passível de imediata execução forçada; a genérica, não. ${ }^{7}$

\footnotetext{
${ }^{4}$ Obrigações de dar, de fazer e de não fazer são delineadas pela certeza (natureza do provimento-espécie do bem jurídico reclamado).

5 O Código de Processo Civil de 2015 não contempla "liquidação para os títulos extrajudiciais"; porém, não significa afirmar a inexistência de eficácia executória dos títulos executivos extrajudiciais que reportem indeterminação para o quantum devido. Um título executivo extrajudicial pode ser objeto de liquidação prévia para o aparelhamento de execução. Basta imaginar a hipótese de um título executivo extrajudicial que consubstancie obrigação de dar coisa certa; se a coisa houver perecido antes mesmo de o credor promover a execução, a obrigação resultante do título será passível de liquidação prévia para a apuração de perdas e danos. Eventual controvérsia a esse respeito decorre da já apontada confusão entre título e obrigação. A liquidez é atributo da obrigação, não se confunde com a eficácia e com a validade do título executivo. Aliás, há títulos judiciais que também são ilíquidos ainda que não provenham de sentença genérica ( $v$.g., sentença penal condenatória, acordos extrajudiciais homologados em juízo, formal e certidão de partilha).
}

${ }^{6}$ Nas sentenças meramente declaratórias, não há a sanção executiva. Já nas sentenças constitutivas, o segundo momento lógico refere-se apenas à constituição, à modificação ou à desconstituição da relação jurídica focada pelo demandante.

7 A lei processual estabelece algumas hipóteses de vedação de condenação genérica, como nos processos que tramitam sob o rito sumaríssimo (parágrafo único do art. 38 da Lei n. 9.099/1995). 


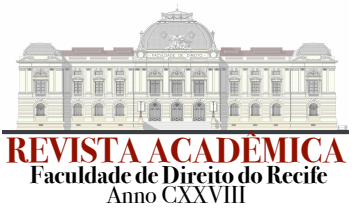

A diferença entre ambas reside exatamente no momento declaratório (o momento sancionatório é o mesmo), que não vai além da existência da obrigação (an debeatur). A decisão de liquidação, assim, acresce à sentença condenatória (sanção já aplicada) o quantum debeatur ainda indefinido na sentença genérica.

A condenação ordinária contém todos os elementos condenatórios, como o bem da vida referente à prestação, acompanhado de suas particularidades, e, além disso, contém a própria sanção executiva. A inexistência da particularidade quantitativa da declaração é o que caracteriza a sentença genérica e o que a faz necessitar de uma fase declarativa complementar, qual seja, a liquidação de sentença. ${ }^{8}$

\section{FASE DE LIQUIDAÇÃO DE SENTENÇA}

\subsection{NATUREZA JURÍDICA}

Não são pacíficas as definições doutrinárias sobre a natureza jurídica da decisão final proferida na fase de liquidação de sentença (que, antes da Lei n. 11.232/2005, sob a égide do CPC/1973, era instaurada por processo autônomo); para alguns autores possui natureza constitutiva (ou constitutivo-integrativa); ${ }^{9}$ para outros, detém natureza declarativa (ou declaratória, ou, ainda, de mero acertamento). ${ }^{10}$ Já sobre sua manifesta natureza cognitiva não pairam dúvidas. A cognição na fase liquidatória, embora exauriente no plano vertical, é limitada no plano horizontal.

\footnotetext{
${ }^{8}$ Evidentemente, o pedido feito na petição inaugural da fase de liquidação não pode ser genérico, deve sempre indicar expressamente o valor pretendido pelo requerente (liquidante); sua admissibilidade encerraria contradição: como liquidar genericamente?

9 “É evidente que a natureza jurídica da sentença de liquidação também é constitutivo-integrativa" (ARRUDA, 1981, p. 112).

10 Esse é o entendimento do Prof. Cândido Rangel Dinamarco (1997, p. 16), que chega a essa conclusão ao apontar a eficácia declaratória-integrativa da decisão proferida em liquidação de sentença, cujo resultado é complementar ao momento declaratório da sentença genérica. E a sentença ilíquida (complementada posteriormente pela decisão de liquidação) não deixa de ser, em razão da iliquidez objeto da condenação, condenatória. "O engano dos que negam tal natureza às sentenças ilíquidas decorre, em primeiro lugar, da falsa premissa de que o título executivo seja por si mesmo criador autônomo e suficiente da ação executiva" (Id., 1998, p. 517).
} 


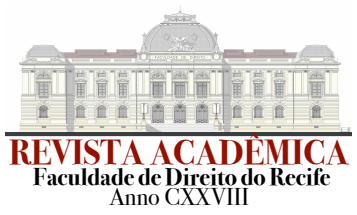

A decisão da fase de liquidação é de natureza cognitivo-declarativa, ${ }^{11}$ que se destina a implementar a declaração do quantum debeatur no primeiro momento lógico (declaratório) da sentença genérica. Portanto, a liquidação destina-se a complementar declarativamente a sentença genérica.

\subsection{OBJETO DA FASE DE LIQUIDAÇÃO}

O objeto da fase de liquidação ${ }^{12}$ é, naturalmente, a apuração do quantum - diferido no momento declaratório da sentença genérica, que se completa apenas quanto ao an debeatur e, portanto, não comporta a rediscussão da demanda. Assim, o objeto litigioso da liquidação é distinto do objeto litigioso do processo que levou à condenação genérica. Seria inadmissível imaginar uma "condenação da condenação".

A liquidação refere-se apenas à quantidade (aspecto da determinação do quantum debeatur). Não pode haver liquidação para determinar a qualidade do que é devido. $\mathrm{O}$ an debeatur é completo na sentença genérica. Por esse motivo, o sistema processual não prevê fase de liquidação para tratar de obrigações diversas das de pagar, como ocorreria, por exemplo, se a parte credora instaurasse liquidação prévia para apurar o resultado prático equivalente mais adequado à satisfação do título. ${ }^{13}$ Nesse caso ilustrativo, a investigação é realizada pelo juiz na fase de tutela específica de obrigação de fazer. ${ }^{14}$ É nessa fase do iter satisfativo que se individua o melhor caminho para cumprir a condenação. Por essa razão, o

${ }^{11}$ É de natureza cognitivo-declarativa porque o juiz declarará parte (do momento declaratório) ainda incompleta da sentença, conhecendo das questões relativas à controvérsia sobre o quantum.

12 No Código de Processo Civil de 1939 (art. 906), a liquidação era fase inicial da execução sempre que houvesse um título sem quantum definido. A inadequação dessa sistemática é, em suma, (i) atribuir pronta eficácia executória a título que não acompanha obrigação líquida e (ii) ignorar que a atividade liquidatória é cognitivodeclarativa, e não executiva (satisfativa).

13 Em Portugal, por exemplo, há previsão de liquidação para a individuação de coisas, especialmente para a individualização dos bens vindicados em demandas que versem sobre universalidades de fato ou de direito.

14 Para a individualização de coisas, na execução de dar coisa fundada em título extrajudicial, a via apropriada para a individualização, em contraste com o caminho traçado pelo processo civil português, parece ser um incidente de concentração da obrigação. 


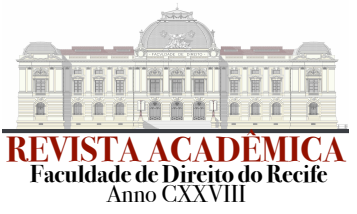

art. 509 do CPC/2015 dispõe que o objeto da liquidação será sempre quantia devida ainda não determinada na sentença. ${ }^{15}$

\subsection{RESPEITO À COISA JULGADA ANTERIOR}

A sentença condenatória genérica contém as diretrizes dos parâmetros liquidatórios, ou seja, contém os elementos que permitem deslindar os limites daquilo que é efetivamente passível de liquidação. Não é possível, em liquidação, extrapolar esses parâmetros, seja para suprimir, seja para preencher alguma lacuna. Quanto mais elementos da obrigação a ser liquidada a sentença condenatória contiver, menos espaço haverá para investigação cognitiva na liquidação (relação de proporção invertida).

Afinal, a decisão proferida em liquidação é complementar à sentença condenatória genérica, jamais pode ser modificativa. $O$ objetivo na liquidação é apenas um: fixar o quantum debeatur, ou seja, resolver uma dúvida objetiva acerca do valor devido (se valor houver).

O pedido que instaura a fase de liquidação deve ser sempre determinado e não pode escapar dos limites transitados em julgado em sede condenatória. Afinal, a função primordial da fase de liquidação é declarativa. Algumas situações suscitam reflexão sobre o tema (respeito à coisa julgada anterior); por exemplo: (i) a possibilidade ou não de alteração de índices financeiros de atualização monetária; (ii) a possibilidade ou não de modificação dos juros de mora; (iii) a possibilidade ou não de sobrevir liquidação improcedente (valor zero).16

A possibilidade de modificação tanto do critério de atualização monetária quanto dos juros moratórios dependerá do fundamento da sentença a ser liquidada que os fixou. Se a sentença aplicar juros de mora legais ou índices oficiais (expressando ou não o índice vigente), não há problema na modificação, pois, nessas hipóteses, a fixação ocorre sob a

15 A liquidação sui generis própria das ações coletivas que versam sobre direitos individuais homogêneos constitui exceção a essa regra, pois, nelas, não apenas o quantum é apurado, mas também outros elementos, inclusive a própria titularidade dos pretensos credores individuais.

16 "No labor da interpretação da sentença deve buscar-se a sua vontade, o conteúdo de seu comando ou preceito, o que deve ser obtido por meio da identificação do ponto de relevância hermenêutica de cada item e dela mesma, consistente na essência de sua vontade, ou seja, o que a sentença quer hoje, porque hoje é que está sendo cumprida, respeitada a coerência com a estabilidade da coisa julgada" (GRECO FILHO, 1997, p. 48). 


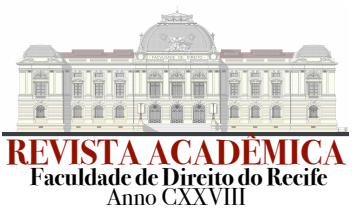

cláusula rebus sic stantibus. 17 Já se a sentença fixar índices (coincidentes ou não com os legais) à luz de outro fundamento jurídico, a alteração a posteriori viola a coisa julgada anterior e, portanto, é inadmissível.

\subsection{INSUFICIÊNCIA DE PROVAS E VALOR ZERO}

Questão mais tormentosa refere-se à possibilidade ou não de, por insuficiência de provas, a liquidação (por artigos) resultar em valor zero: haveria contradição entre julgados?

Existem duas situações distintas que devem ser enfrentadas: (i) o autor não consegue provar, e resulta improcedente a liquidação por artigos; (ii) o autor logra êxito na prova, mas é apurado valor zero, em razão da inexistência de "menos valia" patrimonial, embora a sentença originária indicasse, em tese, que deveria haver.

Há discussão na doutrina acerca da possibilidade ou não de a decisão liquidatória apurar valor zero, já que a sentença anterior conteria uma declaração do crédito previamente existente. Outros, porém, e com mais razão, defendem essa possibilidade. ${ }^{18}$

Parece perfeitamente possível o valor apurado em liquidação ser igual a zero: a sentença originária tem uma dose maior de aparência que de realidade, afinal sua realidade completa reside apenas na sanção. Basta imaginar o exemplo da sentença penal condenatória pelo crime de lesão corporal leve que, constitutiva de título executivo judicial (inc. VI do art. 515 do CPC/2015), seja levada à fase prévia de liquidação. Se, na liquidação, for demonstrado que a lesão foi superficial, que não houve gastos com tratamento nenhum, nem houve lucros cessantes etc., qual seria o fundamento para a obrigatoriedade de a liquidação indicar um valor positivo?

\footnotetext{
17 "Se na sentença ficou determinado valor a ser atualizado por índice hoje não mais existente, não quer dizer que a correção ou atualização tenha desaparecido, porque o ponto de relevância hermenêutica dessa disposição é o de que o valor monetário corresponda, o mais possível, ao valor atual, cabendo ao juiz da execução, interpretando essa vontade, determinar a aplicação do índice mais próximo da realidade monetária, sob pena de ofensa à coisa julgada, porque o que a sentença quer no caso não é o índice ' $a$ ' ou 'b', mas a correção na sua essência" (GRECO FILHO, 1997, p. 48).

18 “O mais razoável e realista é autorizar o juiz a concluir pelo valor zero, sendo arbitrário obrigá-lo a afirmar uma quantidade positiva, em desacordo com os elementos de convicção existentes nos autos; o que lhe é rigorosamente vedado é negar fatos já aceitos na sentença liquidanda ou substituir o juízo ali formulado quanto à obrigação e seus pressupostos" (DINAMARCO, 2004, p. 627).
} 


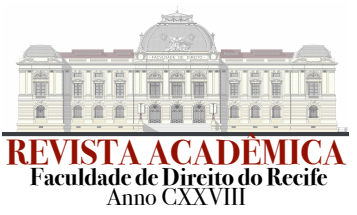

A questão pode ser observada sob uma ótica bastante simples; a sentença genérica profere: "condeno ao valor a ser apurado em liquidação". Se não houver valor apurado, a sentença terá simplesmente perdido sua eficácia para a instauração da fase satisfativa.

Nessas hipóteses, a decisão de liquidação que indica valor zero é de improcedência, e não meramente terminativa, afinal, o liquidante ofereceu liquidação pautado em pretensão numérica (necessidade de indicação de pedido determinado); não acolhida essa pretensão, a fase de liquidação deve ser resolvida com a resolução do mérito, sujeita à coisa julgada e a todas as consequências que a acompanham.

\section{MODALIDADES DE LIQUIDAÇÃO}

A fase de liquidação de sentença continua prevista no novo Código de Processo Civil de modo similar à sistemática do CPC/1973. Sob óptica geral, foram consolidadas as alterações promovidas pela Lei n. 11.232/2005 no Estatuto anterior, foram mantidas as modalidades "ordinárias"19 de liquidação já existentes ("por artigos", agora sob novo título, e "por arbitramento") e foram aportados dispositivos que servem para compatibilizar o sistema com algumas inovações trazidas. Para as duas formas de liquidação "ordinárias" hoje existentes, não houve alteração relevante no regime procedimental.

A chamada liquidação por artigos recebeu o título de "liquidação pelo procedimento comum" (art. 509, II do CPC/2015). A alteração é meramente terminológica e tem razão de ser no fato de a aplicação do rito comum, já imposta pelo CPC/1973 (art. 475-F), permanecer impressa na liquidação por artigos, hoje sob nova denominação.

Há ainda, no sistema processual, uma terceira espécie de liquidação sui generis, prevista na legislação consumerista (art. 97 da Lei n. 8.078/1990 - Código de Defesa do Consumidor), que, na verdade, "é mais que uma liquidação", destinada a "integralizar o título representado pela sentença condenatória genérica em caso de danos a direitos e interesses individuais homogêneos" (DINAMARCO, 1997, p. 26). Essa espécie de liquidação sui

19 Ou figuras de liquidação de sentença do "sistema tradicional", para contrastá-las à liquidação sui generis acrescida em 1990 pelo Código de Defesa do Consumidor (DINAMARCO, 1997, p. 38). 


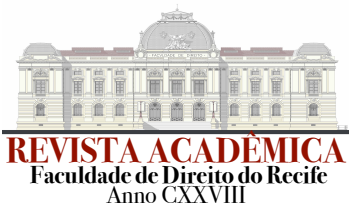

generis não reconhece nem declara a existência de concretos e identificados direitos individuais lesados, e muito menos identifica seus titulares. Com esse vazio na "declaração", há uma abertura cognitiva muito maior, quando comparada às demais hipóteses liquidatórias.

Por disposição expressa (art. 95 do Código de Defesa do Consumidor), a sentença que apreciar esse tipo de demanda será genérica. Trata-se de sentença com eficácia ainda menor do que as sentenças genéricas em geral. A sentença genérica "consumerista" limita-se a reconhecer uma potencialidade danosa, a que passivamente se vincula o réu condenado; inexiste a definição prévia acerca da titularidade ativa dos sujeitos abarcados pela tutela jurisdicional prestada. Ao fim, pode-se inclusive constatar que não havia sequer interessados no aproveitamento da sentença coletiva. Também apenas em fase de liquidação serão constatados os danos concretamente suportados na esfera jurídica dos interessados, que devem habilitar-se no processo (coletivo) ou devem formular autonomamente a liquidação e, se procedente a fase liquidatória, a posterior execução do título.

A chamada liquidação por arbitramento estará presente quando essa modalidade de liquidação estiver determinada na sentença, ${ }^{20}$ ou convencionada pelas partes, ou quando exigida pela natureza do objeto da liquidação (art. 509, I do CPC/2015). O objetivo dessa modalidade é a determinação do valor de bens ou de serviços pela avaliação de um expert, responsável por arbitrar o quantum (evidentemente, o arbitramento não é vinculativo ao juiz).

$\mathrm{Na}$ liquidação por arbitramento, houve uma sutil alteração de rito, comparativamente com o art. 475-D do Estatuto anterior. O novo Código de Processo Civil possibilita a dispensa do arbitramento por terceiro (perito, avaliador), quando os "pareceres ou documentos elucidativos", que deverão ser previamente carreados aos autos pelas partes, permitirem ao juiz "decidir de plano" a liquidação (art. 510 do CPC/2015).

Já a chamada liquidação pelo procedimento comum (a anterior "liquidação por artigos" do CPC/1973) estará presente quando houver a necessidade de alegar e de provar fato

20 Porém, é permitida a alteração a posteriori do procedimento liquidatório, ainda que tenha sido expressamente estipulado na sentença liquidanda. Cf. Enunciado n. 344 da Súmula do Superior Tribunal de Justiça: "a liquidação por forma diversa da estabelecida na sentença não ofende a coisa julgada". 


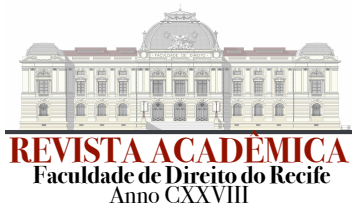

novo (art. 509, II do CPC/2015). ${ }^{21}$ Aqui, a cognição é bem mais ampla, pois é possível o conhecimento de fatos constitutivos do direito do credor não examinados no processo condenatório (fatos supervenientes).

\section{FATO NOVO E LIQUIDAÇÃO}

A superveniência de fato novo, em relação à liquidação, constitui um dos difíceis problemas quanto ao tema. Pode ocorrer que um fato novo sobrevenha em relação à mesma questão controvertida enfrentada na decisão liquidada, ou liquidanda. Por exemplo, em uma demanda reparatória, foi alegada a perda parcial da visão, que, no entanto, progrediu para uma perda total da capacidade visual. Qual seria a solução para o caso, o ajuizamento de uma nova demanda condenatória ou a instauração de nova fase de liquidação?

Para responder à questão, cumpre observar o fenômeno à luz da correlação entre a sentença genérica e o respeito à coisa julgada também gerada pela primeira decisão de liquidação. Se a liquidação trata de fato superveniente, não modificará a decisão liquidatória proferida anteriormente. Se não houver conflito entre os julgados de liquidação - e, claro, sempre impedido o desrespeito à coisa julgada da sentença condenatória $\left(\S 4^{\circ}\right.$ do art. 509 do CPC/2015) -, será possível o oferecimento de nova liquidação. Portanto, é possível a instauração de nova fase de liquidação na hipótese de sobrevirem fatos novos (desde que posteriores à primeira liquidação).

Caso admitida a necessidade de ajuizamento de nova demanda condenatória, aí sim poderia ocorrer violação à coisa julgada. Afinal, como a sanção executória da sentença de condenação já estabeleceu previa e definitivamente a obrigação de reparar, haveria a possibilidade de sobrevir uma sentença de improcedência da segunda demanda, negando o direito à reparação, o que implicaria o conflito de julgados.

\footnotetext{
21 "Considera-se fato novo todo fato constitutivo do direito do autor, não considerado na sentença genérica, mas integrante do contexto gerador da obrigação já reconhecida como existente; um acontecimento que, se tivesse sido considerado na sentença, esta já enunciaria um quantum debeatur desde logo, sem necessidade de ulterior liquidação. Não importa se esse fato ocorreu antes ou depois da prolação da sentença; o que é importa [eis o critério novidade] é que sobre ele não se haja pronunciado o juiz, i.e., que a sua repercussão sobre o valor do crédito não haja sido objeto de decisão" (DINAMARCO, 2004, p. 621).
} 


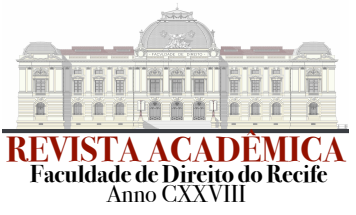

\section{CONTROVÉRSIAS ACERCA DA LIQUIDAÇÃO DE OBRIGAÇÃO REPORTADA POR TÍTULO EXTRAJUDICIAL}

A liquidação, tal como estabelecida no novo Código de Processo Civil (e também no CPC/1973), reporta-se à sentença: liquidação de sentença. Há uma cisão na doutrina acerca da possibilidade de o título executivo extrajudicial referente a obrigação ilíquida dotar-se de força executória, mediante prévia liquidação ou mediante o acompanhamento de documentos escritos comprobatórios da liquidez da obrigação reportada pelo título extrajudicial (elementos externos).

O cerne da discussão merece ser investigado à luz das diferenças entre o título executivo - sua validade e os atributos a ele inerentes - e a obrigação por ele referida. Como já visto, ambos não se confundem. $\mathrm{O}$ título executivo vincula-se à disciplina dos pressupostos essenciais de todo e qualquer tipo de execução (hoje, a qualquer tipo de tutela satisfativa). Sem título, não há como constituir e desenvolver validamente a tutela satisfativa: nulla executio sine titulo. ${ }^{22}$ Não importa a origem do título (judicial ou extrajudicial), todo documento que, por força legal, constituir-se de eficácia executória tem aptidão para instaurar a execução.

O título executivo pode ser definido, assim, como o documento (aspecto formal ou extrínseco) ${ }^{23}$ que, em razão de previsão legal, tem eficácia executória (aspecto material ou intrínseco) tanto para aparelhar o processo executivo stricto sensu quanto para dar continuidade ao processo (sincrético) em sua fase satisfativa (cumprimento de sentença e tutela específica das obrigações). A eficácia executória é atributo inerente ao título executivo; sem ela, não se fala em título executório.

\footnotetext{
${ }^{22} \mathrm{Na}$ tradição jurídica da maior parte dos países europeus, o "título executivo é o pressuposto essencial e constante da execução: ele traz consigo a execução aparelhada (a executio parata dos escritos antigos); e os vários títulos executórios, qualquer que seja sua origem ou natureza - judiciais ou extrajudiciais, públicos ou particulares - são perfeitamente equiparados entre si na eficácia executória que a lei lhes atribui” (ASSIS, 2010, p. 148).

23 É corrente na doutrina italiana a noção de que o título executivo, ante a plurivocidade de significados atribuídos pela lei, representa simplesmente um documento com eficácia executória estabelecida em lei: "è praticamente impossibile fornire una nozione sostanzialmente unitaria del titolo esecutivo, giacché il legislatore attribuisce tale qualità ad atti molto eterogenei, in base a valutazione di opportunità che non a caso variano sensibilmente nel tempo. L'unico criterio utilizzabile, dunque, resta quello formale, per cui sono titoli esecutivi esclusivamente i documenti che la legge definisce tali" (BALENA, 2014, p. 81).
} 


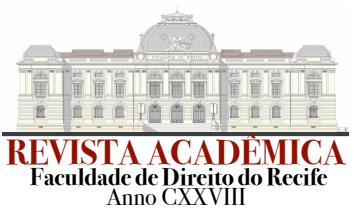

Os títulos ordinariamente executórios são os títulos executivos judiciais, ${ }^{24}$ que se dotam, em razão de sua proveniência (cognição judicial prévia), de maior segurança quanto à eficácia executória. A lei, no entanto, outorga também esse atributo (eficácia executória) a determinados documentos, públicos ou particulares, em razão de política legislativa que prestigia o valor "efetividade", no sopesamento com o valor da "segurança";25 são os títulos executivos extrajudiciais. Os institutos moduladores dessa atribuição "menos segura" são os meios de defesa do executado (processos cognitivos autônomos incidentais, objeções de préexecutividade etc.), que, como se sabe, possuem cognição horizontal mais ampla do que a cognição dos meios de defesa do devedor na fase satisfativa fundada em título executivo judicial (cognição limitada no plano horizontal).

Como visto, a eficácia executória do título não pode ser confundida com os predicados caracterizadores da obrigação a ser tutelada por via satisfativa.

Negar aptidão a adquirir força executória a um título executivo extrajudicial, em razão da ausência de obrigação líquida que o acompanhe, , nessas circunstâncias é ilíquido o próprio título, o que não é verdade. O que é ilíquida é a obrigação; o título permanece válido e, reportando-se a obrigação líquida, certa e exigível, pode materializar todos os efeitos decorrentes de sua eficácia executória.

Aliás, alguns tipos de obrigações, inscritas em títulos executivos extrajudiciais, são naturalmente ilíquidos e, sob tal viés, perderiam sua executividade e fariam "letra morta" a previsão legal que os dota de força executória. Vários títulos executivos extrajudiciais, assim reconhecidos por força legal, não contêm expressão numérica de valor nos documentos que os consubstanciam. No caso dos contratos, aliás, é comum que o valor não esteja expresso no título, como, por exemplo, a inexistência de valores acessórios expressos que, em decorrência de descumprimento do contrato, devam ser exigidos pela via executiva (como o IPTU vencido e não pago pelo locatário, em contrato de locação, o pagamento de mercadoria entregue em

\footnotetext{
${ }^{24} \mathrm{Na}$ tradição europeia, vale ressalvar, já existiam títulos que dispensavam uma execução ex intervallo, "cujas raízes remontam aos processos executivis medieval e à assinação de dez dias das Ordenações [do Reino de Portugal]" (ASSIS, 2010, p. 148).

$25 \mathrm{O}$ justo equilíbrio entre segurança e celeridade é a matriz instituidora de um processo efetivo, que proporcione “às partes o resultado desejado pelo direito material" (BEDAQUE, 2007, p. 49).
} 


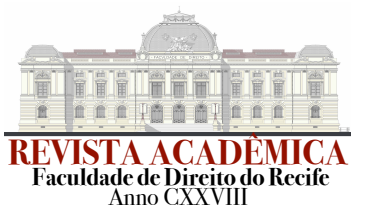

contrato de compra e venda etc.). ${ }^{26}$ Seria necessário, nessas hipóteses, exigir do credor o ajuizamento de demanda cognitiva ou de demanda monitória com objeto apenas na determinação do valor devido?

Evidentemente que, para executar uma obrigação pecuniária, deve haver um valor, embora o montante não precise estar expresso na sentença: basta que haja elementos delineadores para especificar o quantum debeatur, mediante mera elaboração de cálculos. Não expresso no título (condenação genérica), nem sendo o caso de munir a execução com memória de simples cálculos aritméticos, deve ser instaurada a fase de liquidação.

Os títulos executivos extrajudiciais podem dotar-se de força executória não apenas quando submetidos a liquidação prévia, mas também quando for possível a demonstração da liquidez da obrigação por documento (externo) válido que os complemente. A questão é saber o que define a validade desses documentos complementares.

O Superior Tribunal de Justiça, a respeito da liquidez das obrigações referentes a "contratos de abertura de crédito bancário" (cheque especial), considera, em entendimento sumulado, que a juntada de extrato não é apta a aparelhar complementarmente a execução fundada em título executivo extrajudicial; a justificativa: o extrato é documento unilateralmente produzido pelo credor e, por isso, não pode integrar o título. 27

Esse critério, contudo, não parece o mais adequado (produção unilateral ou bilateral) para definir a possibilidade ou não de um documento externo complementar o título extrajudicial para a demonstração da liquidez da obrigação. O documento (complementar) não necessariamente precisa originar-se de produção bilateral para ter eficácia conferida. Em muitos casos, aliás, o documento aditivo é inclusive produzido por terceiros, como na hipótese das guias de recolhimento tributário não quitadas pelo executado, em

\footnotetext{
26 Uma série de outros exemplos é possível: o termo de ajustamento de conduta lavrado pelo Ministério Público, o contrato de corretagem, o contrato de honorários advocatícios ad exitum etc.

27 Enunciado n. 233 da Súmula do Superior Tribunal de Justiça: "o contrato de abertura de crédito, ainda que acompanhado de extrato da conta corrente, não é título executivo”, embora comporte ação monitória (Enunciado n. 247 da Súmula do STJ). "[...] mesmo subscrito por quem é indicado em débito e assinado por duas testemunhas, o contrato de abertura de crédito não é título executivo, ainda que a execução seja instruída com extrato e que os lançamentos fiquem devidamente esclarecidos, com explicitação dos cálculos, dos índices e dos critérios adotados para a definição do débito, pois esses são documentos unilaterais de cuja formação não participou o eventual devedor. Embargos de divergência, por unanimidade, conhecidos, mas, por maioria, rejeitados" (Superior Tribunal de Justiça, Segunda Seção, EREsp n. 108.259/RS, Rel. Min. Sálvio de Figueiredo Teixeira, Rel. p/ acórdão Min. Cesar Asfor Rocha, DJ 20.9.1999; excerto da ementa).
} 


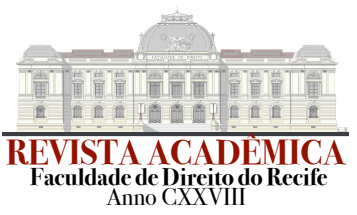

desconformidade com contrato particular que estipulava essa obrigação, celebrado sob as exigências do inc. III do art. 784 do CPC/2015.

Os extratos bancários são documentos de inequívoca ciência do devedor. Apesar de emitidos unilateralmente pela instituição financeira, o executado, em razão do acompanhamento de sua movimentação bancária, tem ciência contínua dos débitos lançados. Caso os extratos contenham elementos de falsidade, invalidade etc., o executado tem instrumentos idôneos de defesa para impugná-los. Este deve ser o critério para definir a possibilidade de um documento externo complementar o título extrajudicial: a bilateralidade da ciência documental - ou a possibilidade de ciência bilateral (no caso em que uma das partes, por omissão, não exerceu seu poder de consulta ao documento) -, porque é à luz da viabilidade de ampla defesa em sede de tutela satisfativa que o problema deve ser enfrentado.

Afinal, a lei, quando define a eficácia executória de determinados títulos executivos extrajudiciais (pautada no valor "efetividade"), não desconhece a necessidade de conferir simetricamente a possibilidade de contraposição de instrumentos de defesa (pautados no valor "segurança") pelo executado. Como mencionado, os meios de defesa do executado são justamente os institutos moduladores da atribuição de eficácia executória ao título extrajudicial e, por isso, possuem cognição horizontal mais ampla do que a cognição dos meios de defesa do devedor na fase satisfativa de títulos decorrentes de sentenças, já que, nestes, há prévia segurança conferida pelo exercício da cognição judicial de origem.

\section{MODIFICAÇÕES GERAIS NO REGIME DE LIQUIDAÇÃO À LUZ DO NOVO CÓDIGO DE PROCESSO CIVIL}

A fase de liquidação de sentença continua prevista no novo Código de Processo Civil de modo similar à sistemática erigida pelo Estatuto de 1973. A chamada liquidação por artigos recebe, agora, o título de liquidação pelo procedimento comum (inc. II do art. 509 do CPC/ 2015). A alteração é meramente terminológica e tem razão de ser no fato de a aplicação do rito comum, já imposta no CPC/1973 (art. 475-F), permanecer impressa na liquidação por artigos, hoje sob nova denominação. 


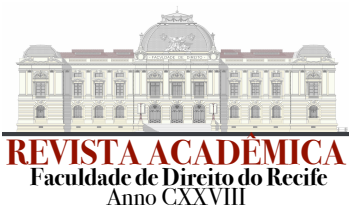

$\mathrm{Na}$ liquidação por arbitramento há uma sutil alteração procedimental. O juiz poderá dispensar o arbitramento por terceiro (perito, avaliador), quando os "pareceres ou documentos elucidativos", que deverão ser previamente carreados aos autos pelas partes, permitirem ao juiz "decidir de plano" a liquidação (art. 524 do CPC/2015).

As hipóteses de cabimento das liquidações por arbitramento e pelo procedimento comum (arts. 510 e 511 do $\mathrm{CPC} / 2015)$ permanecem idênticas àquelas existentes no $\mathrm{CPC} /$ 1973.

Novidade, esta sim, refere-se ao conteúdo da sentença condenatória por quantia certa.28 O novo Código de Processo Civil prevê que a condenação genérica deve conter a máxima extensão possível, com a finalidade de tornar a liquidação menos complexa; ${ }^{29}$ deve vir previamente no título condenatório genérico a fixação do "índice de correção monetária, a taxa de juros, o termo inicial de ambos e a periodicidade da capitalização dos juros” (art. 491 do CPC/2015), ressalvadas as hipóteses de a fixação depender de elementos a serem apurados em liquidação (incisos I e II do art. 491).

$\mathrm{O}$ art. 512 do CPC/2015 estipula que, mesmo na pendência de recurso, poderá ser promovida a chamada liquidação antecipada da sentença, ainda que o recurso pendente esteja dotado de efeito suspensivo, nos termos da inovação já trazida pelo $\S 2^{\circ}$ do art. 475-A do $\mathrm{CPC} / 1973 .{ }^{30}$

A conveniência de nomear o instituto de liquidação antecipada, em vez de por exemplo tratá-lo como liquidação provisória, é explicada pelo fato de a liquidação visar à complementação do título executivo, estabelecido em caráter precário, acrescentando-lhe declaração subsequente (complementação do momento declaratório da sentença a ser liquidada) em relação ao quantum debeatur. O valor apurado na liquidação será definitivo, a

28 Um dos objetivos do novo Código de Processo Civil é reduzir o número de sentenças genéricas (WAMBIER, TALAMINI, 2014, p. 386).

29 A intenção é também a redução do número de condenações genéricas, afinal, "a necessidade de liquidar a obrigação prevista na sentença surge em função de pedido genérico formulado pelo autor quando da propositura da ação condenatória” (ÁLVARES, 2006, p. 113).

30 A expressão liquidação antecipada é utilizada na doutrina para identificar a liquidação antecipatória de que trata o $\S 2^{\circ}$ do art. 475-A do Código de Processo Civil vigente. "O art. 475-A, $\S 2^{\circ}$, autoriza a liquidação na pendência de recurso. Nada se distinguiu quanto aos efeitos da impugnação [recursal], e, portanto, a regra inovou, autorizando a liquidação a despeito do efeito suspensivo do recurso pendente. A essa possibilidade convém designar de liquidação antecipada. Porém, o valor apurado é definitivo, embora sob a condição de que o provimento não sofra alterações na via recursal" (ASSIS, 2010, p. 82-3). 


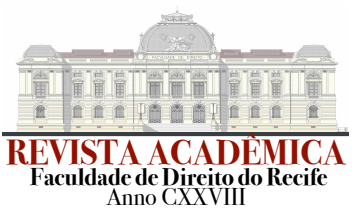

despeito de condicionado ao êxito final da sentença a ser liquidada. Há apenas um diferimento da eficácia do comando liquidatório (de natureza declaratória), que não se confunde com a provisoriedade do título executivo que o acompanha.

A liquidação antecipada, repita-se, é possível ainda que o recurso pendente na fase de conhecimento esteja dotado de efeito suspensivo. O efeito suspensivo do recurso, na fase de conhecimento, obsta a força executória do título: impede a exigibilidade do título mediante execução (lato sensu).

Deve ser recordado que a liquidez não é um atributo do título, mas uma qualidade da obrigação (arts. 783 e 786 do CPC/2015). Assim, pouco importa, à possibilidade de liquidação antecipada, que a eficácia executória - esta sim, atributo do título - esteja ou não autorizada provisoriamente (pendência de recurso sem efeito suspensivo).

\section{CONSIDERAÇÕES FINAIS}

A decisão proferida em fase de liquidação de sentença é de natureza cognitiva declaratório-integrativa, que objetiva implementar no primeiro momento lógico (declaratório) da sentença genérica o quantum debeatur. Portanto, a liquidação destina-se a complementar declarativamente a sentença genérica.

O objeto litigioso da fase de liquidação, que deve ser instaurada mediante pedido determinado (e, claro, também certo), é distinto do objeto litigioso do processo que levou à condenação genérica. Seria inadmissível imaginar uma "condenação da condenação". O objeto da fase de liquidação é a apuração do quantum - diferido no momento declaratório da sentença genérica, que se completa apenas quanto ao an debeatur - e, portanto, não comporta a rediscussão da demanda ( $\left(4^{\circ}\right.$ do art. 509 do CPC/2015).

Se não houver conflito entre os julgados - e, claro, sempre impedido o desrespeito à coisa julgada sobrevinda da sentença condenatória -, será possível o oferecimento de nova liquidação, no caso de sobrevir fato novo, não obstante haja liquidação anterior já encerrada.

É possível a liquidação de títulos executivos extrajudiciais. A eficácia executória do título não pode ser confundida com os elementos caracterizadores da obrigação tutelável por 


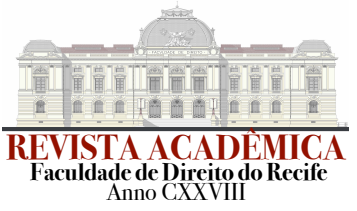

via satisfativa (certeza, exigibilidade e liquidez). O que é ilíquida é a obrigação; o título permanece válido e, reportando-se a obrigação líquida, certa e exigível, pode materializar todos os efeitos decorrentes de sua eficácia executória.

Os títulos executivos extrajudiciais podem dotar-se de força executória não apenas quando submetidos a liquidação prévia, mas também quando for possível a demonstração da liquidez da obrigação por documento (externo) válido que o complemente. O que define a validade desses documentos complementares não é exclusivamente a bilateralidade da produção do documento externo, mas a bilateralidade da ciência do documento - ou a possibilidade de ciência bilateral (no caso em que uma das partes, por omissão, não exerceu seu poder de consulta ao documento) -, porque é à luz da viabilidade de ampla defesa em sede de tutela satisfativa que a questão deve ser enfrentada.

O novo Código de Processo Civil não alterou o regime procedimental da fase de liquidação de sentença. A liquidação por artigos passa a denominar-se liquidação pelo procedimento comum. A alteração é meramente terminológica.

Na liquidação por arbitramento houve uma breve alteração de rito. Segundo o CPC/ 2015, o magistrado pode dispensar o arbitramento por terceiro (perito, avaliador), quando os "pareceres ou documentos elucidativos", que deverão ser previamente carreados aos autos pelas partes, permitirem ao juiz “decidir de plano” a liquidação (art. 510).

$\mathrm{O}$ art. 512 do novo Código de Processo Civil estipula que, mesmo na pendência de recurso, poderá ser promovida a chamada liquidação antecipada da sentença, ainda que o recurso pendente esteja dotado de efeito suspensivo, nos termos da inovação já trazida pelo $\S$ $2^{\circ}$ do art. 475-A do Código de Processo Civil de 1973. A conveniência de nomear o instituto de liquidação antecipada, em vez de por exemplo tratá-lo como liquidação provisória, é explicada pelo fato de a liquidação visar à complementação do título executivo, estabelecido em caráter precário, acrescentando-lhe declaração subsequente (complementação do momento declaratório da sentença a ser liquidada) para a fixação do quantum debeatur.

O valor apurado na liquidação antecipada tem caráter definitivo, a despeito de condicionado ao êxito final da sentença a ser liquidada. Há apenas um diferimento da eficácia do comando de liquidação (de natureza declaratória), que não se confunde com a provisoriedade do título executivo que o acompanha. 


\section{REFERÊNCIAS}

ÁLVARES, Samantha Lopes. Apontamentos sobre o novo regime da liquidação de sentença. In A nova Execução Civil - Lei n. 11.232/2005. Coord. Susana Henriques da Costa, p. 111-27. São Paulo: Quartier Latin, 2006.

ARRUDA, Antonio Carlos Matteis de. Liquidação de sentença. São Paulo: Revista dos Tribunais, 1981.

ASSIS, Araken de. Cumprimento da sentença. 3. ed. Rio de Janeiro: Forense, 2010.

BALENA, Giampiero. Istituzioni di diritto processuale civile: i processi speciali e l'esecuzione forzata. 3. ed. Bari: Cacucci Editore, 2014.

BEDAQUE, José Roberto dos Santos. Efetividade do processo e técnica processual. 2. ed. São Paulo: Malheiros, 2007.

COMOGLIO, Luigi Paolo; FERRI, Corrado; TARUFFO, Michele. Lezioni sul processo civile: II. procedimenti speciali, cautelari ed esecutivi. Bologna: il Mulino, 2011.

DINAMARCO, Cândido Rangel. As três figuras da liquidação da sentença. In Estudos de Direito Processual em Memória de Luiz Machado Guimarães. Coord. José Carlos Barbosa Moreira. Rio de Janeiro: Forense, 1997.

. Execução civil. 6. ed. São Paulo: Malheiros, 1998.

Instituições de direito processual civil. v. IV. São Paulo: Malheiros, 2004.

GRECO FILHO, Vicente. Liquidação e interpretação de sentença. In Atualidades sobre a liquidação de sentença. Coord. Teresa Arruda Alvim Wambier, p. 46-9. São Paulo: Revista dos Tribunais, 1997.

LUCON, Paulo Henrique dos Santos. Eficácia das Decisões e Execução Provisória. São Paulo: Revista dos Tribunais, 2000.

MEDINA, José Miguel Garcia. Processo de execução e cumprimento de sentença. 4. ed. São Paulo: Revista dos Tribunais, 2014.

WAMBIER, Luiz Rodrigues; TALAMINI, Eduardo. Curso avançado de processo civil, v. 1: teoria geral do processo e processo de conhecimento. 14. ed. São Paulo: Revista dos Tribunais, 2014.

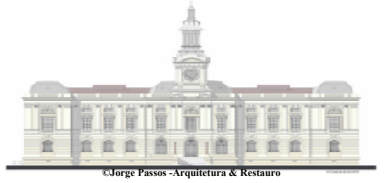

